\title{
ANALISA INDEX PERHITUNGAN RATIO ANGGARAN PENDAPATAN DAN BELANJA DAERAH (APBD) KABUPATEN KULONPROGO YOGYAKARTA PERIODE TAHUN 2007 SAMPAI DENGAN 2011
}

\author{
PANDU CAHYA NUGRAHA \\ Pemerintah Daerah TK II Kulonprogo Yogyakarta \\ pandu.cahya@yahoo.com
}

\begin{abstract}
Abstrak
Penelitian ini bertujuan untuk mengetahui efektifitas penggunaan APBD (Anggaran Pendapatan dan Belanja Daerah) pada daerah Kulonprogo Yogyakarta dalam periodenya. Efektifitas penggunaan APBD ini dilihat dari analisa rasio yang dilakukan kemudian menghitung index pada periodenya, sehingga dapat menggambarkan periode dimana efektifitas lebih baik pada periode tersebut.

Populasi dari penelitian ini adalah seluruh data RLRA (Ringkasan Laporan Realisasi Anggaran) APBD kabupaten Kulonprogo dari awal refisi UU No. 32 tahun 2004 sebanyak 8 periode. Sample yang digunakan adalah data RLRA dari APBD kabupaten Kulonprogo tahun 2007-2011. Analisis data yang digunakan yaitu model indeks perbandingan.

Hasil penelitian menunjukkan bahwa dari 5 periode perhitungan rasio pada APBD kabupaten Kulonprogo menunjukkan tingkat kemampuan daerah mengelola APBD masih tergolong rendah sekali atau masih dalam skala instruktif. Untuk periode efektifitas pengelolaan APBD yang paling baik berdasarkan index perbandingan adalah tahun 2010, sementara periode efektifitas pengelolaan APBD yang paling buruk berdasarkan index perbandingan adalah tahun 2009.
\end{abstract}

Kata kunci: Pemerintahan Daerah, RLRA, Ratio APBD, Index.

\section{PENDAHULUAN}

Berlandaskan undang-undang nomor 32 tahun 2004 tentang pemerintah daerah, pemerintah daerah diberi kewenangan yang luas dalam menjalankan semua urusan pemerintah mulai dari perencanaan, pelaksanaan, pengawasan, pengendalian dan evaluasi kecuali kewenangan bidang politik luar negeri, pertahanan dan keamanan, peradilan, moneter, fiskal, agama dan kewenangan lain yang ditetapkan peraturan pemerintah. Pemberian hak otonomi daerah kepada pemerintah daerah untuk menentukan anggaran pendapatan dan belanja daerah (APBD) sendiri sesuai dengan kebutuhan dan potensi daerah.

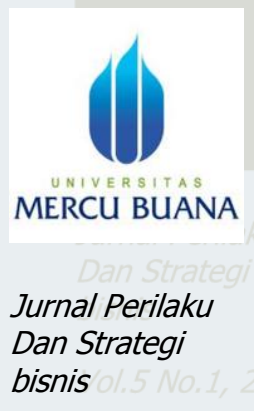

Vol.5 No.1, 2017

Hal. $94-108$ Anggaran pendapatan dan belanja daerah yang dituangkan dalam bentuk kebijaksanaan keuangan pemerintah daerah merupakan salah satu pemicu pertumbuhan perekonomian di daerah tersebut.

Pengukuran kinerja sangat penting untuk menilai akuntabilitas pemerintah daerah dalam melakukan pengelolaan keuangan daerah. Akuntabilitas bukan sekedar kemampuan menunjukan bagaimana uang publik dibelanjakan, akan tetapi meliputi kemampuan yang 
menunjukan bahwa uang publik tersebut telah dibelanjakan secara ekonomis, efisien, dan efektif.

Anggaran pendapatan dan belanja daerah atau biasa disebut APBD merupakan dana yang dianggarkan oleh suatu wilayah kabupaten dalam sebuah propinsi untuk direalisasikan pada tiap periodenya. struktur APBD merupakan satu kesatuan yang terdiri dari Pendapatan Daerah, Belanja daerah, Transfer, dan Pembiayaan.

Keuangan daerah menurut Mamesah (dalam buku Halim, 2004:18) adalah semua hak dan kewajiban yang dapat dinilai dengan uang, demikian pula segala sesuatu baik berupa uang maupun barang yang dapat dijadikan kekayaan daerah sepanjang belum dimiliki/ dikuasai oleh negara atau daerah yang lebih tinggi serta pihak-pihak lain sesuai dengan ketentuan perundang-undangan yang berlaku. Prinsip-prinsip pengelolaan keuangan daerah terdiri dari Transparansi yaitu keterbukaan dalam proses perencanaan, penyusunan dan pelaksanaan anggaran daerah. Akuntabilitas yaitu pertanggungjawaban publik yang berarti bahwa proses penganggaran mulai dari perencanaan atau penyusunan dan pelaksanaan harus benar-benar dapat dilaporkan dan dipertangggungjawabkan kepada DPRD. Dan Value of Money yaitu diterapkan tiga prinsip dalam proses penganggaran yaitu ekonomi, efisiensi, dan efektifitas.

Index adalah Index adalah salah satu ukuran statistik yang tertua, yang dipakai untuk menunjukkan perubahan didalam suatu nilai variabel atau didalam nilai-nilai sekumpulan variabel yang berhubungan satu sama lain. Analisis rasio keuangan pada APBD dilakukan dengan membandingkan hasil yang dicapai dari satu periode dibandingkan dengan periode sebelumnya sehingga dapat diketahui bagaimana kecenderungan yang terjadi. Selain itu dapat pula dilakukan dengan cara membandingkan dengan rasio keuangan daerah lain yang terdekat ataupun yang potensi daerahnya relatif sama untuk dilihat bagaimana posisi rasio keuangan pemerintah tersebut terhadap pemerintah daerah lainnya. Adapun rasio yang bisa dianalisa terhadap APBD adalah Rasio kemandirian keuangan daerah, Rasio derajat disentralisasi fiskal, Rasio keserasian, Rasio pengelolaan belanja, Rasio pertumbuhan.

Rasio kemandirian menggambarkan ketergantungan daerah terhadap sumber dana ekstern. Semakin tinggi rasio kemandirian mengandung arti bahwa tingkat ketergantungan daerah terhadap bantuan pihak ekstern (terutama pemerintah pusat dan provinsi) semakin rendah dan demikian pula sebaliknya. Rasio kemandirian juga menggambarkan tingkat partisipasi masyarakat dalam pembangunan daerah. Semakin tinggi rasio kemandirian, semakin tinggi partisipasi masyarakat dalam membayar pajak dan retribusi daerah akan menggambarkan tingkat kesejahteraan masyarakat yang tinggi (Widodo, 2001 : 262).

Rasio derajat disentralisasi fiskal adalah rasio yang menggambarkan kemampuan pemerintah daerah dalam merealisasikan pendapatan asli daerah yang direncanakan dibandingkan dengan target yang ditetapkan berdasarkan potensi riil daerah. Kemampuan daerah dikatakan efektif apabila rasio yang dicapai minimal 1 (satu) atau 100 persen. Namun semakin tinggi rasio efektifitas, menggambarkan kemampuan daerah yang semakin tinggi (Widodo, 2001: 262).

Rasio keserasian adalah rasio yang menggambarkan bagaimana pemerintah daerah dalam memprioritaskan alokasi dananya pada belanja rutin dan belanja pembangunan secara optimal. Semakin tinggi persentase dana yang dialokasikan untuk belanja rutin berarti 
persentase belanja investasi (belanja pembangunan) yang digunakan untuk menyediakan sarana dan prasarana ekonomi masyarakat cenderung semakin kecil ( Widodo, 2001: 262). Rasio pengelolaan belanja menunjukan bahwa kegiatan belanja yang dilakukan oleh pemerintah daerah memiliki ekuitas antara periode yang positif yaitu belanja yang dilakukan tidak lebih besar dari total pendapatan yang diterima pemerintah daerah. Rasio ini menunjukan adanya surplus atau defisit anggaran. Surplus atau defisit yaitu selisih lebih/ kurang antara pendapatan dan belanja selama satu periode laporan ( Nanik Wahyuni, 2007:94 ).

Rasio pertumbuhan (growth ratio) mengukur seberapa besar kemampuan pemerintah daerah dalam mempertahankan dan meningkatkan keberhasilannya yang telah dicapai dari periode ke periode berikutnya. Dengan diketahuinya pertumbuhan untuk masing-masing komponen sumber pendapatan dan pengeluaran, dapat digunakan untuk mengevaluasi potensi-potensi mana yang perlu mendapat perhatian (Widodo, 2001: 270).

\section{TINJAUAN PUSTAKA}

Untuk menjelaskan variabel-variabel yang ada dalam penelitian ini peneliti mengutip beberapa teori yang berhubungan dengan variabel-variabel penelitian, dan teori-teori ini merupakan landasan dalam penelitian ini. Teori-teori yang digunakan antara lain teori Otonomi daerah, Anggaran Pendapatan dan Belanja Daerah (APBD), struktur APBD, keuangan daerah, kemampuan keuangan daerah, desentralisasi fiskal, index perhitungan APBD, dan analisis rasio APBD.

\section{Otonomi Daerah}

Lahirnya kebijakan otonomi daerah berdasarkan Undang-undang nomor 22 tahun 1999 yang kemudian direvisi dan menjadi Undang-undang nomor 32 tahun 2004 tentang Pemerintahan Daerah merupakan jawaban atas tuntutan reformasi politik dan demokratisasi serta pemberdayaan masyarakat daerah. Setelah selama hampir seperempat abad kebijaksanaan otonomi daerah di Indonesia mengacu kepada Undang-undang Nomor 5 Tahun 1974 tentang Pokok-Pokok Pemerintahan di Daerah yang dibelenggu oleh sistem sentralisasi, pelaksanaan sistem sentralisasi tersebut membawa beberapa dampak bagi penyelenggaraan pemerintahan daerah. Diantaranya yang paling menonjol selama ini adalah dominasi pusat terhadap daerah yang menimbulkan besarnya ketergantungan daerah terhadap pusat. Pemerintah daerah tidak mempunyai keleluasaan dalam menetapkan program-program pembangunan di daerahnya. Demikian juga dengan sumber keuangan penyelenggaraan pemerintahan yang diatur oleh Pusat.

Dalam Undang-Undang No. 32 tahun 2004 pasal 1 ayat 5, pengertian otonomi daerah adalah hak, wewenang, dan kewajiban daerah otonom untuk mengatur dan mengurus sendiri urusan pemerintahan dan kepentingan masyarakat setempat sesuai dengan peraturan perundang-undangan. Sedangkan menurut Suparmoko (2002:61) mengartikan otonomi daerah adalah kewenangan daerah otonom untuk mengatur dan mengurus kepentingan masyarakat setempat menurut prakarsa sendiri berdasarkan aspirasi masyarakat.

Menurut pofesor Oppenhein (dalam Ibrahim 1991:50) daerah otonom merupakan bagian organis dari suatu negara, maka daerah otonom mempunyai kehidupan sendiri yang mandiri dengan kata lain tetap terikat dengan negara kesatuan. Daerah otonomi ini 
merupakan masyarakat hukum yaitu berhak mengatur dan mengurus rumahtangganya sendiri.

\section{Anggaran Pendapatan dan Belanja Daerah (APBD)}

Berdasarkan undang-undang nomor 32 tahun 2004 tentang pemerintah daerah, APBD didefinisikan sebagai rencana operasional keuangan pemerintah daerah, dimana satu pihak menggambarkan perkiraan pengeluaran guna membiayai kegiatan- kegiatan dan proyek-proyek daerah dalam satu tahun anggaran tertentu dan dipihak lain menggambarkan perkiraan penerimaan dan sumber-sumber penerimaan daerah guna menutupi pengeluaranpengeluaran yang dimaksud.

Seperti halnya dalam kebijakan APBN, jika Pemerintah daerah menetapkan bahwa kebijakan anggarannya bersifat ekspansif, artinya APBD akan diprioritaskan untuk menstimulasi perekonomian daerah melalui pengeluaran pembangunan (development budget). Sebaliknya, jika pemerintah daerah menetapkan kebijakan APBD bersifat kontraksi, maka APBD kurang dapat diharapkan untuk menggerakkan perekonomian daerah, karena anggaran pembangunan jumlahnya relatif kecil dibandingkan dengan belanja rutin daerah (Saragih, 2003:82).

Menurut Mamesah (1995:16) APBD sebagai sarana atau alat utama dalam menjalankan otonomi daerah yang nyata dan bertanggung jawab, karena fungsi APBD adalah sebagai berikut:

a. Menentukan jumlah pajak yang dibebankan kepada rakyat dari daerah yang bersangkutan.

b. Merupakan suatu sarana untuk mewujudkan otonomi.

c. Memberikan isi dan arti tanggung jawab pemerintah daerah umumnya dan kepala daerah khususnya, karena APBD itu menggambarkan seluruh kebijaksanaan pemerintah daerah.

d. Merupakan suatu sarana untuk melaksanakan pengawasan terhadap daerah dengan cara yang lebih mudah dan berhasil guna.

e. Merupakan suatu pemberian kuasa kepada kepala daerah dalam batas-batas tertentu.

\section{Struktur APBD}

Pengelolaan keuangan daerah yang berkaitan dengan pelaksanaan desentralisasi diatur secara mendetail dalam Peraturan Menteri Dalam Negeri Nomor 13 Tahun 2006 (yang kemudian dilengkapi dengan Peraturan Menteri Dalam Negeri Nomor 59 Tahun 2007) menyatakan bahwa dalam pelaksanaan desentralisasi daerah, pemerintah daerah berhak menyelenggarakan pengelolaan keuangan daerah, yang komponen-komponennya sebagaimana tertuang dalam struktur APBD antara lain terdiri dari:

a. Pendapatan Daerah

Pendapatan daerah adalah semua penerimaan kas yang menjadi hak daerah dan diakui sebagai penambah nilai kekayaan bersih dalam satu tahun anggaran dan tak perlu dibayar lagi oleh pemerintah.

b. Belanja Daerah

Belanja daerah adalah semua pengeluaran kas daerah atau kewajiban yang diakui sebagai pengurang nilai kekayaan bersih dalam periode satu tahun anggaran yang tidak akan diperoleh pembayarannya kembali oleh pemerintah. Klasifikasi belanja menurut urusan pemerintahan terdiri atas belanja urusan wajib dan belanja urusan pilihan.

c. Transfer 
Transfer adalah penerimaan/ pengeluaran uang dari suatu entitas pelaporan lain, termasuk dana perimbangan dan dana bagi hasil.

d. Pembiayaan

Pembiayaan adalah setiap penerimaan yang perlu dibayar kembali dan atau pengeluaran yang akan diterima kembali, baik pada pada tahun anggaran yang bersangkutan maupun pada tahun-tahun anggaran berikutnya, yang dalam penganggaran pemerintah terutama dimaksudkan untuk untuk menutup defisit atau memanfaatkan surplus anggaran.

Menurut Saragih (2003:82), apapun komposisi dari APBD suatu daerah tentu harus disesuaikan dengan perkembangan keuangan pemerintah daerah yang bersangkutan. Setiap daerah tidak harus memaksakan diri untuk menggenjot pengeluaran tanpa diimbangi dengan kemampuan pendapatannya, khususnya kapasitas PAD. Dikhawatirkan jika pemerintah daerah menetapkan kebijakan defisit pada APBD-nya, maka sumber pembiayaan untuk menutupi sebagian atau seluruh defisit anggaran berasal dari pinjaman atau utang.

\section{Keuangan Daerah}

tersebut Menurut Pasal 1 Peraturan Pemerintah Nomor 58 Tahun 2005, keuangan daerah adalah "Semua hak dan kewajiban yang dapat dinilai dengan uang, demikian pula segala sesuatu, baik uang maupun barang yang dijadikan milik daerah berhubungan dengan pelaksanaan hak dan kewajiban daerah".

Keuangan daerah menurut Mamesah (dalam buku Halim, 2004:18) adalah semua hak dan kewajiban yang dapat dinilai dengan uang, demikian pula segala sesuatu baik berupa uang maupun barang yang dapat dijadikan kekayaan daerah sepanjang belum dimiliki/ dikuasai oleh negara atau daerah yang lebih tinggi serta pihak-pihak lain sesuai dengan ketentuan perundang-undangan yang berlaku. Prinsip-prinsip pengelolaan keuangan daerah tersebut adalah:

a. Transparansi, adalah keterbukaan dalam proses perencanaan, penyusunan dan pelaksanaan anggaran daerah.

b. Akuntabilitas, adalah pertanggungjawaban publik yang berarti bahwa proses penganggaran mulai dari perencanaan atau penyusunan dan pelaksanaan harus benarbenar dapat dilaporkan dan di pertangggung jawabkan kepada DPRD.

c. Value for money, berarti diterapkan tiga prinsip dalam proses penganggaran yaitu ekonomi, efisiensi, dan efektifitas.

Sementara itu, untuk dapat memiliki keuangan yang memadai dengan sendirinya daerah membutuhkan sumber keuangan yang cukup pula. Dalam melaksanakan keuangan daerah perlu dibuatkan suatu perencanaan agar seluruh kegiatan yang akan dilaksanakan dapat dikelola dengan baik. Bentuk perencanaan keuangan daerah inilah yang dikenal dengan istilah Anggaran Pendapatan dan Belanja Daerah (APBD), sebagaimana telah digariskan dalam Undang-undang Nomor 33 Tahun 2004 tentang Perimbangan Keuangan Antara Pemerintah Pusat dan Pemerintahan Daerah.

\section{Kemampuan Keuangan Daerah}

Kriteria penting untuk mengetahui secara nyata kemampuan daerah untuk mengatur dan mengurus rumah tangganya adalah kemampuan daerah dalam bidang keuangan. Dengan kata lain, faktor keuangan merupakan faktor yang penting dalam mengatur tingkat kemampuan daerah dalam melaksanakan otonomi daerah. 
Peraturan Pemerintah No. 105 tahun 2000 menyebutkan bahwa keuangan daerah adalah semua hak dan kewajiban daerah dalam rangka penyelenggaraan pemerintah daerah yang dapat dinilai dengan uang termasuk didalamnya segala bentuk kekayaan lain yang berhubungan dengan hak dan kewajiban daerah tersebut dalam kerangka Anggaran Penerimaan dan Belanja Daerah (APBD).

\section{Desentralisasi Fiskal}

Otonomi daerah dan termasuk di dalamnya desentralisasi fiskal mengharuskan daerah mempunyai kemandirian keuangan yang tinggi. Beberapa daerah dengan sumber daya yang dimiliki mampu menyelenggarakan otonomi daerah, namun tidak tertutup kemungkinan ada beberapa daerah akan menghadapi kesulitan dalam menyelenggarakan tugas desentralisasi, mengingat keterbatasan sumber daya yang dimiliki (Bappenas, 2003:1).

Menurut Saragih (2003:83), yang dimaksud dengan desentralisasi fiskal adalah suatu proses distribusi anggaran dari tingkat pemerintahan yang lebih tinggi kepada pemerintahan yang lebih rendah, untuk mendukung fungsi atau tugas pemerintahan dan pelayanan publik, sesuai dengan banyaknya kewenangan bidang pemerintahan yang dilimpahkan. Dan dalam pelaksanaannya, prinsip money should follow functionmerupakan salah satu prinsip yang harus diperhatikan dan dilaksanakan.

Tabel 1. skala interval derajat desentralisasi fiskal

\begin{tabular}{ll}
\hline Interval \% & Kemampuan Keuangan Daerah \\
$0,00-10,00$ & Sangat Kurang \\
\hline $10,01-20,00$ & Kurang \\
$20,01-30,00$ & Cukup \\
$30,01-40,00$ & Sedang \\
$40,01-50,00$ & Baik \\
$>50,00$ & Sangat Baik \\
\hline Sumber : Depdagri dan Fisipol UGM (1991) dalam Wulandari (2001)
\end{tabular}

\section{Index Dalam Perhitungan Rasio}

Index adalah salah satu ukuran statistik yang tertua, yang dipakai untuk menunjukkan perubahan didalam suatu nilai variabel atau didalam nilai-nilai sekumpulan variabel yang berhubungan satu sama lain. Jika kita menyatakan nilai ekspor pada tahun 1963 sebgai persentase dari nilai ekspor pada tahun 1950, maka angka yang meunjukkan persentase itu dinamakan angka index nilai ekspor. Angka index ini dapat menunjukkan nilai ekspor pada tahun 1963 dibandingkan dengan nilai ekspor pada tahun1950. Kalau kita mencatat harga beras perkilogram di kota medan setiap hari dan menyatakan harga beras itu sebagai persentase dari harga pada suatu hari tertentu, atau sebagai persentase dari rata-rata hitung harga beras pada suatu minggu atau suatu bulan, maka bilangan-bilangan yang menunjukkan persentase itu adalah angka index juga. Pada hal yang terakhir ini, angka index itu dipakai untuk menunjukkan perubahan yang bersambung, perubahan dari hari ke hari (Pasaribu Amadi. 1975. Pengantar Statistik). Dalam hal ini index diartikan prosentase perhitungan APBD periode tertentu yang dijadikan tahun dasar acuan prosentase perhitungan APBD periode lainnya. 


\section{Analisa Rasio APBD}

Penggunaan analisis rasio pada sektor publik khususnya terhadap APBD belum banyak dilakukan sehingga secara teori belum ada kesepakatan secara bulat mengenai nama dan kaidah pengukurannya. Meskipun demikian dalam rangka pengelolaan keuangan daerah yang transparan, jujur, demokratif, efektif, efisien dan akuntabel, analisis rasio terhadap APBD perlu dilaksanakan meskipun kaedah dalam perakuntansian APBD berbeda dengan laporan keuangan yang dimiliki oleh perusahaan swasta.

Analisis rasio pada Anggaran Pnerimaan dan Belanja Daerah (APBD) dilakukan dengan membandingkan hasil yang dicapai dari satu periode dibandingkan dengan periode sebelumya sehingga dapat dietahui kecenderungan yang terjadi. Selain itu dapat pula dilakukan dengan cara membandingkan dengan rasio keuangan yang dimiliki suatu pemerintah tertentu dengan rasio keuangan daerah lain yang terdekat maupun yang potensi daerahnya relatif sama untuk dilihat bagaimana posisi rasio keuangan Pemerintah Daerah tersebut dengan Pemerintah Daerah lainnya.

\section{METODOLOGI PENELITIAN}

\section{Populasi dan Sampel}

Populasi dalam penelitian ini adalah seluruh data RLRA (Ringkasan Laporan Realisasi Anggaran) APBD kabupaten Kulonprogo dari awal refisi UU No. 32 tahun 2004 sebanyak 8 periode.

Metoda pengambilan sampel yang digunakan dalam penelitian ini adalah non probalistic sampling khususnya teknik purposive sampling. Kriteria pemilihan sampel dalam penelitian ini adalah :

1. Merupakan data APBD Kulonprogo yang berakhir 31 desember selama 5 tahun terakhir.

2. Memiliki kelengkapan pencatatan tiap bulannya.

Berdasarkan kriteria di atas diperoleh sampel RLRA tahun 2007-2011.

\section{Variabel Penelitian}

Variabel penelitian adalah obyek penelitian atau apa yang menjadi titik perhatian suatu penelitian. Variabel dependen dalam penelitian ini adalah Index rasio APBD. Variabel independen dalam penelitian ini adalah rasio kemandirian, rasio derajat disentralisasi fiskal, rasio keserasian, dan rasio pertumbuhan.

1. Index rasio $\mathrm{APBD}(\mathrm{Y})$

Index adalah salah satu ukuran statistik yang tertua, yang dipakai untuk menunjukkan perubahan didalam suatu nilai variabel atau didalam nilai-nilai sekumpulan variabel yang berhubungan satu sama lain. Pada APBD kabupaten Kulonprogo ini periode yang digunakan sebagai tahun dasar perhitungan index adalah tahun 2010. Tahun 2010 dipilih sebagai tahun dasar perhitungan index karena memiliki prosentase PAD yang paling tinggi, serta memiliki prosentase realisasi belanja yang lebih rendah dibandingkan tahun lainnya. (supranto, statistik untuk pimpinan \& perusahaan, 1982)

$$
I_{t}=\frac{p t}{p o} \times 100
$$

$$
\begin{aligned}
& I_{t}=\text { index rasio } \\
& \text { pt }=\text { nilai pada waktu } t \\
& \text { Po }=\text { nilai pada waktu o }
\end{aligned}
$$


2. Rasio kemandirian keuangan daerah (X1)

Rasio Kemandirian Keuangan Daerah menunjukkan tingkat kemampuan suatu daerah dalam membiayai sendiri kegiatan pemerintah, pembangunan dan pelayanan kepada masyarakat yang telah membayar pajak dan retribusi sebagai sumber pendapatan yang diperlukan daerah. Rasio kemandirian ditunjukkan oleh besarnya pendapatan asli daerah dibandingkan dengan pendapatan daerah yang berasal dari sumber lain ( pihak ekstern ) antara lain : Bagi hasil pajak, Bagi hasil bukan pajak sumber daya alam, Dana alokasi umum dan Alokasi khusus, Dana darurat dan pinjaman (Widodo, $2001:$ 262).

Rasio ini dapat dihitung dengan menggunakan rumus :

\section{Rasio kemandirian $=\frac{\text { Pendapatan Asli Daerah }}{\text { Sumber Pendapatan Eksternal }}$}

3. Rasio derajat desentralisasi fiskal (X2)

Derajat desentralisasi fiscal atau otonomi fiscal daerah adalah kemampuan pemerintah daerah dalam rangka meningkatkan pendapatan asli daerah guna membiayai pembangunan ( Widodo, 2001: 262).

Rasio ini dapat dihitung dengan menggunakan rumus :

$$
\text { derajat desentralisasi fiskal }=\frac{P A D_{t}}{T P D_{t}} \times 100 \%
$$

$P A D_{t}=$ Total pendapatan asli daerah tahun $\mathrm{t}$

$T P D_{t}=$ Total pendapatan daerah tahun $\mathrm{t}$

4. Rasio Keserasian (X3)

Rasio Keserasian ini menggambarkan bagaimana pemerintah daerah memprioritaskan alokasi dananya pada belanja rutin dan belanja pembangunan secara optimal. Semakin tinggi persentase dana yang dialokasikan untuk belanja rutin berarti belanja pembangunan yang digunakan untuk menyediakan sarana prasarana ekonomi masyarakat cenderung semakin kecil (Widodo, 2001: 262).

Rasio ini dapat dihitung dengan menggunakan rumus (tim penyusun modul program pendidikan non gelar auditor sektorpublik) :

\section{Rasio keserasian $=\frac{\text { Total belanja langsung }}{\text { Total belanja tidak langsung }}$}

5. Rasio pertumbuhan (X4)

Rasio pertumbuhan menggambarkan seberapa besar kemampuan pemerintah daerah dalam mempertahankan dan meningkatkan keberhasilan yang dicapai dari periode keperiode lainya. Pertumbuhan APBD dilihat dari berbagai komponen penyusun APBD yang terdiri dari pendapatan asli daerah, total pendapatan, belanja rutin dan belanja pembangunan (Widodo, 2000: 270).

Rasio ini dapat dihitung dengan menggunakan rumus :

$$
\text { Rasio pertumbuhan }=\frac{P_{n}-P_{o}}{P_{o}} \times 100 \%
$$

$P_{n}=$ Data yang dihitung dari tahun ke-n

$P_{o}=$ Data yang dihitung pada tahun ke-o 


\section{Teknik Analisis Data}

Hasil analisis kuantitatif deangan meggunakan rasio APBD selanjutnya dibandingkan dengan standar penilaian kemampuan keuangan daerah. Hasil perbandingan ini sebagai dasar pengambilan kesimpulan kondisi kemampuan keuangan daerah kabupaten Kulonprogo. Adapun standar penilaian kemampuan keuangan daerah adalah:

Tabel 2. Klasifikasi Tingkat Kemampuan Kemandirian Daerah

\begin{tabular}{lll}
\hline Kemampuan Keuangan & Kemandirian (\%) & Pola Hubungan \\
\hline Rendah sekali & $0 \%-25 \%$ & instruktif \\
Rendah & $26 \%-50 \%$ & konsultatif \\
Sedang & $51 \%-75 \%$ & partisipatif \\
Tinggi & $76 \%-100 \%$ & delegatif \\
\hline
\end{tabular}

Sumber :Halim (2002)

\section{HASIL DAN PEMBAHASAN \\ Analisa Rasio APBD}

\section{Rasio Kemandirian}

Rasio kemandirian kabupaten Kulonprogo selama tahun anggaran 2007-2011 mengalami kenaikan maupun penurunan, namun tidak terlalu signifikan. Pada tahun 2007 rasio kemandirian mencapai $7,98 \%$ atau masih bersifat instruktif dan pada tahun 2008 turun menjadi 7,83\%. Pada tahun 2009 turun menjadi 7,06\% penurunan ini disebabkan karena tahun 2009 Indonesia sedang menjalani pemilu presiden yang mengakibatkan pendapatan PAD dari sektor pariwisata dan retribusi daerah lainnya mengalami penurunan sehingga pola hubungan masih bersifat instruktif. Selanjutnya pada tahun 2010 mengalami kenaikan menjadi 8,25\%. Pada tahun 2011 terjadi penurunan kembali menjadi $7,28 \%$.

Jika dihat dari tahun ke tahun pola kemandirian keuangan cenderung mengalami peningkatan walaupun relatif kecil, tapi masih dalam pola instruktif dari tahun pertama sampai tahun ke 5 .

2. Rasio Derajat Desentralisasi Fiskal

Pada tahun 2007 rasio Derajat desentralisasi fiskal sebesar 7,39\% sehingga peran daerah dalam pembangunan masih sangat kurang. Di tahun 2008 Derajat desentralisasi fiskal turun menjadi 7,26\%. Di tahun 2009 Derajat desentralisasi fiskal mencapai 6,6\%. Penurunan rasio ini terjadi karena pendapatan dari pusat mengalami peningkatan yang cukup signifikan sedangkan pendapatan asli daerah tumbuh relatif kecil. Hal ini disebabkan karena pada tahun 2009 kabupaten Kulonprogo sedang heboh persiapan pemilu presiden Indonesia sehingga PAD tidak optimal. Sedangkan pendapatan dari pemerintah pusat meningkat sebagai dana aktivitas pemilihan umum pada tiap daerah. Selanjutnya pada tahun 2010 rasio desentralisasi fiskal menjadi 7,62\%. Di tahun ini pendapatan asli daerah meningkat cukup tinggi namun dibarengi dengan kenaikan pendapatan daerah yang masih cukup tinggi. Pada tahun 2011 terjadi penurunan kembali besarnya rasio desetralisasi fiskal menjadi $6,79 \%$. Tahun ini kabupaten Kulonprogo sebenarnya mendapatkan PAD yang meningkat namun pendapatan eksternal guna 
mencukupi kebutuhan belanja pada tahun tersebut juga meningkat lebih besar sehingga rasio derajat disentralisasi ditahun ini mengalami penurunan. Sedangkan rata-rata derajat disentralisasi fiskal dalam kurun waktu 5 tahun tersebut adalah 7,13\% sehingga rasio derajat desentralisasi fiskal kabupaten Kulonprogo masih dikatakan sangat kurang dalam tingkat kemampuan daerah.

3. Rasio Keserasian Belanja

Dari olah data didapatkan bahwa tahun 2007 rasio keserasian sebesar 67,94\%. Ini berarti belum terjadi keserasian belanja karena belanja tidak langsung masih lebih besar dibandingkan belanja langsung. Pada tahun 2008 mengalami penurunan menjadi 56,18\% Ini menunjukan semakin tidak adanya keserasian belanja ditahun 2008 dibandingkan tahun 2007 karena rasio keserasian mengalami penurunan. Tahun 2009 dan tahun 2010 pun rasio ini terus mengalami penurunan yaitu 29,89\% pada tahun 2009 dan 29,31\% pada tahun 2010. Rasio keserasian terus menurun rata-rata $12,87 \%$ pada empat tahun tersebut. Sedangkan pada tahun 2011 rasio keserasian naik sebesar 15,19\% ke angka 44,5\%. Walaupun tidak lebih besar dibanding angka pada tahun 2007 dan 2008 setidaknya rasio keserasian bergerak kearah yang positif.

4. Uji Autokorelasi

Pertumbuhan PAD di kabupaten Kulonprogo pada tahun 2008 meningkat menjadi Rp 42.289.208.476 atau bertumbuh sebesar 9,45\% dari tahun 2007 sebesar Rp 38.637.833.503. Di tahun 2009 PAD menurun menjadi Rp 39.358.629.412 atau bertumbuh sebesar $-6,93 \%$. Tahun 2010 pertumbuhan PAD mengalami peningkatan sebesar 22,66\% di angka Rp 48.280.640.675. Kemudian tahun 2011 pertumbuhan PAD meningkat kembali sebesar 11,33\% di angka Rp 53.752.293.431.

TPD (Total Pendapatan Daerah) untuk tahun 2007 sebesar Rp 522.937.813.610. Di tahun 2008 TPD meningkat menjadi Rp 581.934.155.009 atau bertumbuh sebesar 11,28\%. Tahun 2009 pertumbuhan TPD kembali meningkat sebesar 2,49\% di angka Rp 596.428.928.201. Kemudian tahun 2010 pertumbuhan TPD meningkat kembali sebesar 6,14\% di angka Rp 633.088.918.846. Dan tahun 2011 pertumbuhan TPD meningkat tinggi sebesar 25,07\% di angka Rp 791.826.637.868.

BTL (Belanja Tidak Langsung) untuk tahun 2007 sebesar Rp 293.463.109.279. Di tahun 2008 BTL meningkat menjadi Rp 382.928.557.673 atau bertumbuh sebesar 30,48\%. Tahun 2009 pertumbuhan BTL kembali meningkat sebesar 16,15\% di angka Rp 444.766.627.124. Kemudian tahun 2010 pertumbuhan BTL meningkat kembali sebesar 6,56\% di angka Rp 473.959.882.626. Dan tahun 2011 pertumbuhan BTL meningkat sebesar 13,98\% di angka Rp 540.214.639.691.

BL (Belanja Langsung) untuk tahun 2007 sebesar Rp 199.376.997.814. Di tahun 2008 BL meningkat menjadi Rp 215.131.354.044 atau bertumbuh sebesar 07,9\%. Tahun 2009 pertumbuhan BL menurun tajam sebesar 38,19\% di angka Rp 132.970.368.976. Kemudian tahun 2010 pertumbuhan BL meningkat kembali sebesar 4,49\% di angka Rp 138.942.748.540. Dan tahun 2011 pertumbuhan BL meningkat sangat tinggi sebesar 73,02\% di angka Rp 240.405.422.562. 
Tabel 3. Index Rasio

\begin{tabular}{lccccc}
\hline \multicolumn{1}{c}{ Index Rasio } & 2007 & 2008 & 2009 & 2010 & 2011 \\
\hline Rasio kemandirian & 0,96 & 0,94 & 0,85 & 1 & 0,88 \\
Rasio DDF & 0,96 & 0,95 & 0,86 & 1 & 0,89 \\
Rasio keserasian belanja & 2,31 & 1,91 & 1,01 & 1 & 1,51 \\
$\begin{array}{l}\text { Rasio Pertumbuhan } \\
\text { a. PAD }\end{array}$ & - & 0,4 & $-0,3$ & 1 & 0,5 \\
b. TPD & - & 1,83 & 0,4 & 1 & 4,08 \\
c. BTL & - & 4,64 & 2,46 & 1 & 2,13 \\
d. BL & - & 1,75 & $-8,5$ & 1 & 16,2 \\
\hline
\end{tabular}

Sumber: Data Diolah (2013).

\section{Pembahasan}

Dalam pembahasan ini dijelaskan alasan atau penyebab naik atau turunnya nilai index rasio pada tiap periodenya. Dalam tiap analisa rasio akan dijelaskan penyebab terjadinya penurunan atau kenaikan index.

Untuk index pada rasio kemandirian tahun 2007 terhitung sebesar 0,96 di tahun ini pendapatan asli daerah realisasinya tidak begitu jauh dari anggaran setelah perubahan namun ada uraian PAD yang berkurang dari anggaran setelah perubahan yaitu pada hasil pengelolaan kekayaan daerah yang dipisahkan berkurang sebesar 12,15\%. Pada tahun 2008 nilai index sebesar 0,94 juga tidak terlalu berbeda, disisi hasil pengelolaan kekayaan daerah yang dipisahkan berkurang dari anggaran setelah perubahan sebanyak 89,33\%. Tahun 2009 nilai index sebesar 0,85 mengalami banyak uraian dari PAD yang berkurang dari anggaran setelah perubahan yaitu Hasil pajak daerah (92,77\%), Hasil pengelolaan kekayaan daerah yang dipisahkan $(88,00 \%)$, Lain lain PAD yang sah $(85,02 \%)$. Banyaknya uraian dari PAD yang berkurang dari anggaran setelah perubahan dikarenakan terjadinya kemarau panjang di tahun ini yang mengakibatkan komuditas perekonomian di daerah berkurang. Tahun 2011 index pada rasio kemandirian sebesar 0,88 di tahun ini pendapatan asli daerah realisasinya tidak begitu jauh dari anggaran setelah perubahan namun kembali lagi ada uraian PAD yang berkurang dari anggaran setelah perubahan yaitu pada hasil pengelolaan kekayaan daerah yang dipisahkan berkurang sebesar 7,48\%.

Untuk index pada rasio derajat disentralisasi fiskal tahun 2007 terhitung sebesar 0,96 di tahun ini kemampuan pemerintah daerah dalam rangka meningkatkan pendapatan asli daerah guna membiayai pembangunan cukup baik dibandingkan tahun lain kecuali tahun dasar 2010 walaupun memang jika dilihat dari acuan analisa rasio terhitung masih sangat kurang untuk perkembangan daerah otonomi. Tahun 2008 index pada rasio derajat disentralisasi fiskal terhitung sebesar 0,95, di tahun ini PAD memang mengalami perkembangan namun dari pendapatan eksternal sebagai dana perimbangan guna mencukupi kebutuhan aktivitas pemerintahan juga mengalami peningkatan. Tahun 2009 index pada rasio derajat disentralisasi fiskal terhitung sebesar 0,86 ini adalah nilai index paling buruk dalam 5 periode anggaran yang dianalisa dimana PAD mengalami penurunan sementara pendapatan eksternalnya bertambah untuk perimbangan jalannya Pemilu Presiden di tahun ini. Tahun 2011 index pada rasio derajat disentralisasi fiskal sebesar 0,89 memang tidak lebih besar dibanding 2007 \& 2008 namun lebih membaik dibanding tahun 2009. 
Untuk index pada rasio keserasian yang memperlihatkan index belanja pada APBD kulonprogo tahun 2007 terhitung sebesar 2,31 di tahun ini nilai index paling besar dibanding 4 periode lainnya karena selisih dalam prosentase belanja langsung dan tidak langsung masih besar, karna ditahun ini total pendapatan yang dihasilkan untuk APBD masih kecil, sehingga menghambat kinerja oprasional pemerintahan. Tahun 2008 index pada rasio keserasian didapati sebesar 1,91 sudah hampir mendekati tahun dasar index, namun pada tahun ini terjadi devisit pada realisasi APBD dikarenakan belanja daerah lebih besar dibandingkan pendapatannya. Tahun 2009 index pada rasio keserasian didapati sebesar 1,01 nilai yang paling mendekati index tahun dasar, ini berarti jumlah belanja tidak langsung semakin lebih besar dibandingkan belanja langsung yang artinya alokasi belanja untuk pembangunan lebih besar. Namun apa yang terjadi di lapangan secara umum belum nampak perkembangan pembangunan yang signifikan ditahun ini. Tahun 2011 index pada rasio keserasian didapati sebesar 1,51 ini tidak jauh berbeda dengan tahun sebelumnya index belanja tidak langsung masih lebih besar dibandingkan index belanja langsung.

Untuk index rasio pertumbuhan tahun 2008 PAD menunjukkan nilai 0,4 ini berarti pertumbuhan PAD meningkat dari tahun 2007 dari uraian lain-lain pendapatan asli daerah yang sah tahun 2007 memang lebih besar namun pada uraian retribusi daerah 2008 jauh lebih besar dibanding tahun 2007. Dari TPD index didapati senilai 1,83 ini berarti TPD tahun 2008 lebih besar dibanding tahun dasar index yaitu 2010 atau lebih besar 0,83, pendapatan besar karna dana perimbangan yang dianggarkan cukup besar untuk aktivitas pemerintahan. Dari BTL didapat sebesar 4,64 belanja tidak langsung yang digunakan untuk meningkatkan pembangunan, pertumbuhan pada belanja ini dikarenakan Kulonprogo sedang memproyekkan pelabuhan di kawasan Glagah. Dari BL didapat sebesar 1,75 berarti tahun 2008 index belanja langsung bertumbuh dari tahun 2007.

Untuk index rasio pertumbuhan tahun 2009 PAD menunjukkan nilai $-0,3$ ini berarti pertumbuhan PAD menurun dari tahun 2008 dari uraian hasil retribusi daerah menunjukkan penurunan drastis dari sisi PAD tahun 2008 ke 2009 ini terjadi karena tahun ini komoditas perekonomian mengalami penurunan akibat kemarau panjang yang terjadi di tahun ini. Dari TPD index didapati senilai 0,4 ini berarti TPD tahun 2009 bertumbuh, dana perimbangan yang dianggarkan cukup besar untuk mengimbangi aktivitas perekonomian tahu ini. Dari BTL didapat sebesar 2,46 belanja tidak langsung yang digunakan untuk meningkatkan pembangunan, belanja tidak langsung dianggarkan lebih dominan untuk memperbaiki kondisi perekonomian ditahun ini. Dari BL didapat sebesar $\quad-8,5$ berarti tahun 2009 index belanja langsung mengalami penurunan perkembangan yang terjadi karena anggaran APBD dialokasikan lebih besar ke belanja tidak langsung.

Untuk index rasio pertumbuhan tahun 2011 PAD menunjukkan nilai 0,5 ini berarti pertumbuhan PAD meningkat dari tahun dasar 2010 uraian-uraian untuk PAD seluruhnya lebih besar dibanding tahun 2010. Dari TPD index didapati senilai 4,08 ini berarti TPD tahun 2011 lebih besar dibanding tahun dasar index yaitu 2010 atau lebih besar 3,08, pendapatan besar karna dana perimbangan yang dianggarkan cukup besar untuk aktivitas pemerintahan. Dari BTL didapat sebesar 2,13 belanja tidak langsung yang digunakan untuk meningkatkan pembangunan, pertumbuhan pada belanja ini dikarenakan tiap tahunnya kebutuhan untuk pembangunan terus meningkat. Dari BL didapat sebesar 16,2 nilai index yang sangat tinggi didapati ditahun ini dikarenakan uraian-uraian Belanja Langsung 
semuanya mengalami peningkatan berarti tahun ini pemerintahan sangat boros menganggarkan APBD untuk Pemda.

\section{KESIMPULAN DAN SARAN}

\section{Kesimpulan}

Dari hasil penelitian dan analisis pada bab sebelumnya maka dapat diambil kesimpulan sebagai berikut:

1. Berdasarkan Rasio Kemandirian Keuangan daerah kabupaten Kulonprogo tahun anggaran 2007-2011 berada pada kisaran 7.92 - 13.27\%. Semua masih dalam skala interval $0 \%-25 \%$ dan tergolong mempunyai pola hubungan yang instruktif berdasarkan standar keuangan daerah, yang berarti peran pemerintah pusat masih sangat tinggi dalam memenuhi kebutuhan dana untuk penyelenggaraan tugas-tugas pemerintah, pembangunan dan pelayanan sosial masyarakat masih relatif rendah. Meskipun dari tahun ke tahun rasio tersebut terus meningkat, tetapi tingkat ketergantungan pada sumber pendapatan dari pihak eksternal cukup tinggi, disebabkan oleh masih lebih besarnya proporsi sumber pendapatan oleh Pemerintah Pusat, daripada dari PAD nya. Sementara jika dilihat dari indexnya tahun 2010 yang dijadikan tahun dasar pengujian menunjukkan angka index rasio kemandirian keuangan yang paling baik, karna keempat tahun uji lainnya berada di bawah 1 atau $<1$ karna ini berarti pada tahun dasar nilai perbandingan pendapatan asli daerah dengan pendapatan eksternal untuk kemandirian pemerintah daerah lebih baik dibandingkan tahun uji lainnya.

2. Berdasarkan rasio derajat disentralisasi fiskal, bahwa kemampuan pemerintah daerah dalam rangka meningkatkan pendapatan asli daerah guna membiayai pembangunan masih dalam skala interval 0,00\% - 10,00\% atau dalam kategori sangat kurang. Pemerintah kabupaten Kulonprogo masih sangat bergantung pada sumber keuangan yang berasal dari pemerintah pusat walaupun terjadi peningkatan dari sisi PAD tiap tahunnya. Dari sisi index juga bisa kita lihat tahun 2007, 2008, 2009, dan 2011 nilainya $<1$ yang berarti nilai index tahun 2010 sebagai tahun dasar merupakan tahun yang index DDFnya paling baik, yang artinya ditahun ini kemampuan pemerintah dalam meningkatkan pendapatan asli daerah paling baik dibanding tahun lainnya.

3. Berdasarkan Rasio keserasian belanja di kabupaten Kulonprogo sebagai gambaran bagaimana pemerintah daerah memprioritaskan alokasi dananya pada belanja rutin dan belanja pembangunan secara optimal menunjukkan bahwa pada tahun 2007-2011 berada pada kisaran 29,31\%-67,94\% belum menunjukkan keserasian karna <100\% atau 1. Sementara dari nilai index keserasian tahun 2007, 2008, 2009, dan 2011 nilainya $>1$ yang berarti belanja langsung berbanding belanja tidak langsung tidak optimal karna jumlah anggaran berbanding tipis. Karna semakin besar belanja tidak langsung yang dianggarkan maka anggaran untuk pembangunan juga lebih besar.

4. Berdasarkan rasio pertumbuhan di kabupaten Kulonprogo tahun anggaran 2008-2011 berada pada kisaran $7.92-13.27 \%$. Semua masih dalam skala interval $0 \%-25 \%$ dan tergolong mempunyai pola hubungan yang instruktif berdasarkan standar keuangan daerah. Dari sisi index pertumbuhan, index belanja langsung didapati paling tinggi sebesar 16,2 tahun 2011 sementara index paling rendah didapati -8,5 juga dari index belanja langsung tahun 2009 . 


\section{SARAN}

Berdasarkan kesimpulan di atas, maka saran yang dapat diberikan adalah sebagai berikut:

1. Untuk mengurangi tingkat ketergantungan daerah, terutama penerimaan DAU dari pemerintah pusat maka pemerintahan daerah kabupaten Kulonprogo pastinya harus meningkatkan pendapatan dari sisi PAD sehingga tidak lagi terlalu mengandalkan pendapatan eksternal untuk menjalankan pemerintahan dan dalam melaksanakan pembangunan. Hal ini dapat terlaksana dengan mengutamakan pengalokasian dana APBD untuk belanja tidak langsung yang akan digunakan untuk pembangunan sehingga komoditas perekonomian di kabupaten ini akan bertumbuh dan menghasilkan banyak pemasukan dari sisi PAD.

2. Berdasarkan nilai index dengan tahun dasar 2010 maka pemerintah daerah Kulonprogo dapat menjadikannya patokan untuk menggunakan APBD pada tahun berikutnya. Agar setidaknya memiliki gambaran penggunaan alokasi APBD yang baik.

3. Memasukkan banyak investasi dari luar kabupaten dengan cara promosi investasi yang akan mengundang para investor datang dan berinvestasi di Kulonprogo. Karena dengan adanya investasi yang masuk maka pergerakan ekonomi di Kulonprogo akan bertumbuh cepat akibat aktivitas ekonomi yang besar.

\section{DAFTAR PUSTAKA}

Adi Darmawan, Jihad. 2011. Analisis Rasio Anggaran Pendapatan dan Belanja Daerah (APBD) untuk menilai kinerja keuangan pemerintah daerah kabupaten Bantul. Skripsi S1, Universitas Mercu Buana Yogyakarta, tidak dipublikasikan.

Halim, Abdul. 2002. Akuntansi Sektor Publik. Jakarta: Salemba Empat. 2007. Akuntansi Sektor Publik. Jakarta: Salemba Empat.

Indriyanto, N \& Bambang S. 2002. Metodologi Penelitian Bisnis untuk Akuntansi dan Manajemen. Yogyakarta: BPFE Universitas Gadjah Mada.

Liuqing, Mai. (2012). Trading costs around M\&amp;A announcements", International Journal of Managerial Finance, Vol. 8 Iss: 2 pp. 120 - 138.

Mamesah D.J., 1995, Sistem Administrasi Keuangan Daerah, Gramedia, Jakarta.

Mardiasmo. 2002. Otonomi dan Manajemen keuangan daerah. Yogyakarta: Andi Ibrahim, M.J. 1991. Prospek Otonomi Daerah. Semarang: Dahara Prise. Munawir, S. 1995. Analisa laporan keuangan. Yogyakarta: Liberty.

Mardiasmo, 2002. Perpajakan : Edisi Revisi tahun 2002, Andi Yogyakarta, Yogyakarta.

Nataludin. 2001. Potensi Dana Perimbangan pada Pemerintahan di Daerah Propinsi Jambi, Manajemen Keuangan Daerah. Yogyakarta: UPP YKPN.

Rahman. 2012. Kulonprogo kurang dilirik investor. Harian Jogja: Yogyakarta.

RLRA, 2007-2011., DPPKA dan KPT Kulonprogo. Yogyakarta. 
Rosa, Yulinda. 2009. Metode analisa data variabel sosial bidang permukiman. Bandung: Pusat litbang pemukiman.

Republik Indonesia. 2006. Peraturan Mentri Dalam Negeri Nomor 13 Tahun 2006 tentang disentralisasi fiskal.

Republik Indonesia. 2001. Peraturan Pemerintah Nomor 65 Tahun 2001 tentang Pajak Daerah.

Republik Indonesia. 2001. Peraturan Pemerintah Nomor 66 Tahun 2006 tentang Retribusi Daerah.

Republik Indonesia. 2000. Peraturan Pemerintah Nomor 58 Tahun 2005 tentang Pengelolaan dan Pertanggungjawaban Keuangan Daerah.

Setiaji, W. \& Adi, W. 2007. Peta kemampuan keuangan sesudah otonmi daerah : Apakah mengalami pergeseran?. Simposium Nasional Akuntansi X. Makasar.

Sidik, Machfud, 2000. Kebijakan Fiskal Nasional untuk Mendukung Otonomi Daerah, disampaikan pada seminar otonomi daerah dalam rangka Lustrum I MEP UGM,Yogyakarta.

Suparmoko. 2002. Ekonomi Publik. Yogyakarta: Andi.

Undang-Undang Republik Indonesia Nomor 32 Tahun 2004 Tentang Pemerintahan Daerah.

Undang-Undang Republik Indonesia Nomor 33 Tahun 2004 Tentang Perimbangan Keuangan antara pusat dan daerah.

Widodo. 2001. Analisa Rasio Keuangan Pada APBD Kabupaten Boyolali, Manajemen Keuangan Daerah. Yogyakarta: UUP YKPN.

Wulandari. 2001. Disentralisasi keuangan pemerintahan daerah. Yogyakarta: Fisipol UGM.

Wahyuni, Nanik. 2007. Teori Administrasi Publik.: Alfabeta. Bandung.

Widjaja. 1998. Percontohan otonomi daerah di Indonesia. Jakarta: Rineka Cipta.

Yuliati. 2001. Analisis Kemampuan Keuangan Daerah dalam menghadapi Otonomi Daerah. Yogyakarta: UPP YKPN.

Sumber : Kulon Progo Dalam Angka 2011, Bappeda. 26/04/2012., http://www.kulonprogokab.go.id/v21/Geografis_9_hal 